\title{
The Determinants of Capital Structure of the Chemical Industry in Pakistan
}

\author{
Muhammad Rafiq $^{*}$, Asif Iqbal ${ }^{* *}$, Muhammad Atiq $^{* * *}$
}

\section{Abstract}

This study is an attempt to determine the capital structure of listed firms in the chemical industry of Pakistan. The study finds that by studying a specific industry's capital structure, one can ascertain unique attributes, which are usually not apparent in the combined analysis of many sectors as done by Shah and Hijazi (2004). This study analyzed 26 of 39 firms in the chemical sector, listed at the Karachi Stack Exchange for the period 1993-2004 using pooled regression in a panel data analysis. Six regressors i.e. firm size, tangibility of assets, profitability, income variation, non-debt tax shield (NDTS) and growth were employed to examine their effects on leverage. The results show that these six independent variables explain 90\% of variation in the dependent variable and, except for firm tangibility, results were found to be highly significant. The study has policy implications of importance for researchers, investors, analysts and managers.

JEL Classification: C13, C23, C51, L65

Keywords: Chemical, Panel Data, Karachi Stock Exchange, Pakistan

\section{Introduction}

A firm can combine different proportions of debt and equity in an attempt to increase the market value of the firm and is recognized as capital structure of the firm. Firms differ with respect to capital structure which has given birth to different capital structure theories in an attempt by researchers to explain variation in capital structure over time or across regions.

Modigliani and Miller (1958) demonstrated that the market value of a firm is determined by its earning power and the risk of its underlying

\footnotetext{
* Assistant Professor, Institute of Management Sciences, Peshawar.

${ }^{*}$ Research Assistant, Institute of Management Sciences, Peshawar.

${ }^{* * *}$ Lecturer, CECOS University, Peshawar.
} 
assets, and is independent of the way it chooses to finance its investments or distributes dividends. Moreover, a firm can choose between three methods of financing: issuing shares, borrowing or spending profits (as opposed to disbursing them to shareholders as dividends). The theorem gets much more complicated, but the basic idea is that under certain assumptions, it makes no difference whether a firm finances itself with debt or equity.

Although this theory is based on many unrealistic assumptions, it provides the basic theoretical background for further research. After Modigliani and Miller, a lot of research was done on optimal capital structure and the determinants of capital structure. During this period, among others, three main theories emerged to explain the behavior of the firm in choosing its capital structure. These are Static Tradeoff Theory, Pecking Order Theory and the Signaling Theory.

In Pakistan, the first thorough study with regards to the determinants of capital structure of stock exchange-listed, non-financial firms of Pakistan was conducted by Shah and Hijazi (2004). Their work is considered a good start, considering the neglect of Financial Economics topics by researchers in Pakistan. However, it has been pointed out that the study is based on only six years of data, and by updating the data set and using a longer data set, results can be improved. Besides this, the inclusion of some important explanatory variables, which are important for corporate decision making, may make the study more valuable. Moreover, the empirical evidence suggests that there is significant industry influence on capital structure. So, analyzing sectors individually may produce better results.

The present study has been designed to address these shortcomings and to find out industry-specific determinants of capital structure by taking the chemical sector as a case study. Furthermore, an attempt has also been made to elucidate the policy implications of the model and to make suggestions for analysts, managers, investors, and researchers. Here, it must be stressed that it is a pioneering work in the field of the non-financial sector in Pakistan.

\section{Theoretical Framework}

\subsection{Static Trade-Off Theory}

Static Trade-Off Theory (STT) explicates that a firm follows a target debt-equity ratio and then behaves accordingly. The benefits and costs 
linked with the debt option sets this target ratio. These include taxes, cost of financial distress and agency costs.

\subsection{Pecking Order Theory}

Pecking Order Theory (POT) theory was put forward by Myers and Majluf (1984). It postulates that firms follow a hierarchy of financial decisions when establishing its capital structure.

Initially, firms prefer to finance their projects through internal financing, i.e. retained earnings. In case they need external financing, first they apply for a bank loan then for public debt. As a last resort, the firm will issue equity to finance a project. Thus, according to POT, profitable firms are less likely to incur debt for new projects because they have the available internal funds for this purpose. The reason firms are reluctant to issue equity is because of asymmetric information between management and new stockholders. Myers and Majluf (1984) pointed out that under-pricing would be the result of less information held by potential investors vis-à-vis management with respect to the expected cash flows from the firm's assets, both current and future. Considering these information asymmetries, investors would infer that the management would issue stock only when it is overpriced. Thus the newly issued equity might be sold at a discount. This would be regarded as a wealth transfer from existing investors to the new ones. This problem could be avoided if the firms use internally generated resources, such as retained earnings.

Moreover, Pecking Order Theory has a more important effect on capital structure for firms that are managed in the interests of equity holders, rather than the combined interests of debt and equity holders.

However, when financial distress costs are high, equity-maximizing and value-maximizing firms make similar capital structure choices (Titman and Tsyplakov, 2005).

Myers (1977) suggests that firms acting to maximize the interests of equity holders will be reluctant to issue equity because of the wealth transfer to debt holders, while Myers and Majluf (1984) propose that firms are reluctant to issue equity because of an adverse selection problem. Titman (2005) and Stultz (1990) suggest that firms may be reluctant to issue equity because of the costs associated with being scrutinized. Finally issuing equity involves substantial transaction costs. Tong and Green (2005) have provided empirical evidence which support the pecking order hypotheses. 
Moreover, Delcoure (2007) have also provided fresh evidence in support of pecking order theory.

These theories are not mutually exclusive. Firms can choose target ratios that reflect the benefits and costs of debt financing put forth in the trade-off literature, but may deviate from their targets for the reasons described in the pecking order literature.

\subsection{Signaling Theory}

The Signaling Theory (ST) approach, originally developed by Ross (1977), explains that debt is considered a way to highlight investors' trust in the company; that is, if a company issues the debt it provides a signal to the markets that the firm is expecting positive cash flows in the future, as the principal and interest payments on debt are a fixed contractual obligation which a firm has to pay out of its cash flows. Thus the higher level of debt shows the manager's confidence in future cash flows.

Another impact of the signaling factor, as we have already discussed it in the Pecking Order Theory, is the problem of the under-pricing of equity, If a firm issues equity instead of debt for financing its new projects, investors will interpret the signal negatively; since managers have superior information about the firm than investors, they might issue equity when it is overpriced.

Among other explanations about a firm's behavior in choosing its capital structure is agency theory. Jensen and Meckling (1976) identify the possible conflict between shareholders and a manager's interests because the manager's share is less than $100 \%$ in the firm. Furthermore, acting as an agent to shareholders, the manager tries to appropriate wealth from bondholders to shareholders by incurring more debt and investing in risky projects.

This is consistent with the work of Myers (1977) who argues that, due to information asymmetries, companies with high gearing would have a tendency to pass up positive NPV (net present value) investment opportunities (under-investment problems). Myers therefore argues that companies with large amounts of investment opportunities (also known as growth options) would tend to have low gearing ratios.

A manager having a less than $100 \%$ stake in the business may try to use these free cash flows sub-optimally or use it to their own advantage rather than use it to increase the value of the firm. Jensen (1986) suggests 
that this problem can be somehow controlled by increasing the stake of the manager in the business or by increasing debt in the capital structure, thereby reducing the amount of "free" cash available to managers to engage in their own pursuits (Jensen, 1986; Stultz, 1990). Here the reduction in the cash flow because of debt financing is considered to be a benefit.

Stultz (1990) suggests that the agency problem can be solved to some extent if the management stake is increased or the proportion of debt in the capital structure is increased.

\section{Methodology}

This section provides information about the source of data, sample size, measurement of the variables and discussion of different measures of the variables.

\subsection{Sources of Data}

The study has made use of twelve years data published by the State Bank of Pakistan, "Balance Sheet Analysis of Joint Stock Companies Listed on The Karachi Stock Exchange Volume-II 1993-1999" and "Balance Sheet Analysis of Joint Stock Companies Listed on The Karachi Stock Exchange Volume-II 1999-2004."

\subsection{Sample}

This study has focused on the Chemical Sector, and initially all the 39 firms (which are listed on the Karachi Stock Exchange) in the chemical sector (whose published data was available) were selected. After screening the data, firms with incomplete data were dropped and the remaining 26 firms were selected for panel data analysis.

\subsection{Dependent and Independent Variables}

The study used profitability (PF), tangibility of assets (TG), size of the firm (SZ), growth (GT), income variation (IV) and non-tax debt shield (NDTS) as explanatory variables to determine the degree of leverage (LG) (the response variable). This section presents the description of these variables, how they are measured and what empirical evidence was found by previous studies. The choice regarding the included explanatory variables has been made based on a review of the relevant literature. 


\subsubsection{Leverage (LG) (Dependent Variable)}

Leverage refers to the percentage of assets financed by debt. Previous research studies have used different measures of leverage. Frank and Goyal (2003) state that the difference between a debt ratio based on market value and one based on book values is that the former tends to regard the firm's future situation whereas the latter reflects the past situation. Fama and French (2000) point out some inconsistencies arising from the use of two different debt ratios. According to them, both theories (Pecking Order and Static Tradeoff) apply to the debt book value, and there are doubts if the predictions may be extended to the debt market value.

Consistent with a previous study on non-financial Pakistani listed firms by Shah and Hijazi (2004), this study has used the book value measure of leverage. The main benefit of debt is that the interest payments are taxdeductible and thus provides cash savings. These tax shield benefits are not changed by the market value of the debt once it is issued (Banerjee et. al., 2000). So the market value of the debt is irrelevant for this study.

On the other hand, the primary cost of borrowing is the increased chance of bankruptcy. If a firm falls in financial distress and goes into bankruptcy, then the relevant value of the debt is the book value of the debt, not the market value of the debt (Shah and Hijazi, 2004).

Another consideration when deciding on the appropriate measure of leverage is to take total debt or only long term debt as a percentage of total assets. Though capital structure theories consider long term debt as a proxy for financial leverage, this study has used the measure of total debt because in Pakistan, firms have mostly short term financing, as the average firm size is small. This makes access to the capital market difficult in terms of cost and technical difficulties (Shah and Hijazi, 2004). In Pakistan, firms usually prefer short term borrowing, the reason being that commercial banks are the major lenders and they do not encourage long term loans. Up until 1994, firms did not rely on market based debt; in mid 1994 the government amended the Company Law to permit companies to raise debt directly from the market in the form of TFCs (Term Finance Certificates).

Booth et. a1. (1999) also pointed out in their study on determinants of capital structure in developing countries (including Pakistan) that the use of short term financing is greater than long term financing in developing countries. 


\subsection{Independent Variables}

\subsubsection{Profitability (PF)}

Profitability is a strong point of dissent between the two theories i.e. Pecking Order Theory (POT) and Static Tradeoff Theory (STT). For STT, the higher the profitability of the firm, the more reasons it will have to issue debt, reducing its tax burden. On the other hand, the POT presupposes that larger earnings lead to the increase of the main source firms choose to cover their financial deficit: retained earnings. Therefore, the STT expects a positive relationship between profitability and leverage, whereas the POT expects exactly the opposite.

In previous studies, the measure of profitability used was operating earnings before interest payments and income tax (EBIT). But following Shah and Hijazi (2004) and Tariq and Hijazi (2006), this study measures profitability (PF) as the ratio of net income before taxes divided by total assets because the data taken from the State Bank of Pakistan publication does not permit us to calculate EBIT (Shah and Hijazi, 2004; Tariq and Hijazi, 2006).

Thus the first hypothesis is that firms with higher profitability will have less leverage.

Tong and Green (2005) has also provided empirical evidence regarding this relationship.

\subsubsection{Tangibility of Assets (TG)}

Firms having a large amount of fixed assets can easily raise debt at cheaper rates because of the collateral value of those fixed assets. The companies with a higher ratio of tangible assets have an incentive to borrow more because loans are available to them at relatively cheaper rates. Therefore this study expects a positive relationship between tangibility of assets and leverage.

According to the static tradeoff approach, firms with a higher ratio of fixed assets serve as collateral for new loans, favoring debt. However, Pecking Order Theory is of the view, as argued by Harris and Raviv (1990), that firms with low levels of fixed assets would have more problems of asymmetric information, making them issue more debt, since equity issues would only be possible by under-pricing them. On the other hand, firms with higher levels of asset tangibility are generally larger firms that can issue 
equity at fair prices, so they do not need to issue debt to finance new investment. According to them, the expected relationship between asset tangibility and debt should then be negative.

Tangibility of assets is measured in this study as the ratio of fixed assets to total assets, taking the total gross amount of fixed assets as the numerator. Using total gross fixed assets rather than net depreciated value of assets makes sense as different firms may possibly use different depreciation methods that may create unevenness in the data.

A firm can pledge an asset having a market value even if it has been fully depreciated. Calculating tangibility this way, the ratio was above one in some cases suggesting that total gross fixed assets were more than total assets (Shah and Hijazi, 2004).

Therefore the second hypothesis is that firms with a higher percentage of fixed assets will have higher debt ratios.

\subsubsection{Size (SZ)}

With respect to the Pecking Order Theory, Frank and Goyal (2003) and Rajan and Zingales (1995) argued that this relationship could be negative. There is less asymmetric information about the larger firms, reducing the chances of the undervaluation of new equity issues, encouraging large firms to use equity financing. This means that there should be a negative relationship between size and leverage of the firm.

For the Static Tradeoff approach, the larger the firm, the greater the possibility it has of issuing debt, resulting in a positive relationship between debt and size. One of the reasons for this is that the larger the firm, the lower is the risk of bankruptcy. Large firms do not consider the direct bankruptcy costs as an active variable in deciding the level of leverage as these costs are fixed by the Constitution and constitute a smaller proportion of the total firm's value and also because larger firms, being more diversified, face a lower probability of bankruptcy (Titman and Wessels, 1988).

Shah and Hijazi (2004) also found a positive relationship between size and leverage of the firm, so this study expects positive relation between size and leverage of the firm.

Size (SZ) of the firm is measured by the taking the natural $\log$ of the sales to smoothen the variation over the periods considered. 
Therefore the third hypothesis is that there is a positive relationship between size and leverage of firms.

\subsubsection{Growth (GT)}

Rajan and Zingales (1995) suggest that one would expect a negative relationship between growth opportunities and the level of gearing. This is consistent with the theoretical predictions of Jensen and Mekling (1976) based on agency theory, and the work of Myers (1977) who argues that, due to information asymmetries, companies with high gearing would have a tendency to pass up positive NPV (net present value) investment opportunities. Myers therefore argues that companies with large amounts of investment opportunities (also known as growth options) would tend to have low gearing ratios.

Moreover, as growth opportunities do not yet provide revenue, companies may be reluctant to take on large amounts of contractual liabilities at this stage. Similarly, as growth opportunities are largely intangible, they may provide limited collateral value or liquidation value (in a similar spirit to the discussion of tangibility below).

However, the empirical evidence regarding the relationship between gearing and growth opportunities is rather mixed. Titman and Wessels (1988), Barclay et al. (1995), Rajan and Zingales (1995), and Shah and Hijazi (2004) find a negative correlation, whereas Kester (1986) does not find any support for the predicted negative relationship between growth opportunities and gearing. This is therefore consistent with the hypotheses of Jensen and Meckling (1976) and Myers (1977), and lends weight to the notion that companies with high levels of growth opportunities can be expected to have low levels of gearing.

For the POT there are two possibilities for the sign of this variable; on the one hand, firms with high growth opportunities would tend to keep their debt ratios at low levels so as to preserve their credit capacity when it becomes necessary (negative impact), and on the other hand, this growth requires investments which are usually made with the issue of new debt (positive impact). Fama and French (2000) named these two possibilities as the complex and simple versions of the POT, respectively.

Different studies have used varying measures of growth like market to book value of equity, research expenditure to total sales measure and annual percentage increase in total assets (Titman and Wessels, 1988). Given the structure of data, this study measures growth (GT) as a percentage 
increase in total assets, as the data was taken from the State Bank of Pakistan's publication which does not have information on annual stock prices and research expenditure of the listed firms (Shah and Hijazi, 2004).

Thus the study expects a positive coefficient for growth. The fourth hypothesis is that firms with higher growth rates will have higher leverage.

Delcoure (2007) has substantiated the same argument and has provided evidence on a positive relationship between the aforementioned variables.

\subsubsection{Income Variation}

Income variation is considered to be either the inherent business risk in the operations of a firm or a result of inefficient management practices. In either case, earnings volatility is a proxy for the probability of financial distress and the firm will have to pay a risk premium to outside providers of funds. To reduce the cost of capital, a firm will first use internally generated funds and then outsider funds. This suggests that earnings volatility is negatively related with leverage. This is the combined prediction of trade-off theory and pecking order theory. However, Cools (1993) says that agency theory suggests a positive relationship between earnings volatility and leverage. $\mathrm{He}$ says that the problem of underinvestment decreases when the volatility of a firm's returns increases. Following the prediction of trade-off theory and pecking order theory, this study expects negative relationship between income variation (IV) and leverage.

Several measures of volatility are used in different studies, such as the standard deviation of earnings before interest and tax (Booth et a1., 2001), standard deviation of the first difference in operating cash flow scaled by total assets (e.g., Bracley et. a1., 1995; and Wald, 1999), standard deviation of the percentage change in operating income (e.g., Titman and Wessels, 1988). As standard deviation gives a single value for a given variable, the current study cannot use this measure with panel data. Alternatively, this study uses the value of the deviations from mean of net profit divided by total number of years for each firm in the given year as a proxy for earnings volatility.

Thus the fifth hypothesis is that income variation (IV) is negatively related to leverage. 


\subsubsection{Non-Debt Tax Shields}

Non-debt tax shields (NDTS) include depreciation and investment tax credits. DeAngelo and Masulis (1980) say that non-debt tax shields can be substitutes for the tax benefits of debt financing and a firm with larger nondebt tax shields is expected to use less debt. The study therefore expects a negative relationship between NDTS and leverage. Wald (1999) uses the ratio of depreciation to total assets and Chaplinsky and Niehaus (1993) employ the ratio of depreciation expense plus investment tax credits to total assets to measure NDTS. Both studies find that leverage is negatively correlated with NDTS. In this study, annual depreciation charges divided by total assets to calculate non-debt tax shields is used.

Our sixth hypothesis is that NDTSs are negatively related to leverage.

\subsection{Analytical Technique}

This study uses panel regression analysis. Panel data analysis facilitates analysis of cross-sectional and time series data. The study uses the pooled regression type of panel data analysis. Pooled regression, also called the Constant Coefficients model, is one where both intercepts and slopes are assumed constant. The cross-sectional company data and time series data are pooled together in a single column assuming that there is no significant cross-sectional or inter-temporal effects. Many other studies on this subject matter have used the same analytical technique. Other studies (for example Shah and Hijazi, 2004; and Hall, Hutchinson and Michaelas, 2004) have employed the same analytical technique.

Therefore the equation for our regression model will be:

$\mathrm{LG}=\beta_{0}+\beta_{1}(\mathrm{TG})+\beta_{2}(\mathrm{SZ})+\beta_{3}(\mathrm{GT})+\beta_{4}(\mathrm{PF})+\beta_{5}(\mathrm{IV})+\beta_{6}(\mathrm{NDTS})+\mathrm{e}$

Where

$$
\begin{aligned}
& \text { LG = Leverage } \\
& \text { TG = Tangibility of assets } \\
& \text { SZ = Firm Size measure by log of sales } \\
& \text { GT = Growth } \\
& \text { PF = Profitability } \\
& \text { IV = Income variation } \\
& \text { NDTS = Non-debt tax shield } \\
& \text { e = Error term }
\end{aligned}
$$




\section{Analysis and Results}

Checking for multicollinearity among predictor variables, Spearman's Correlation among them is checked, which is given in Table-1.

Table-1: Correlations Among Independent Variables (A Check for Multicollinearity)

\begin{tabular}{lcccccc}
\hline & Growth & Tangibility & Size & NDTS & Profitability & $\begin{array}{c}\text { Income } \\
\text { Variation }\end{array}$ \\
\hline Growth & 1 & .004 & .001 & -.037 & -.189 & -.577 \\
Tangibility & .004 & 1 & .035 & -.253 & .006 & .039 \\
Size & .001 & .035 & 1 & .121 & -.441 & .350 \\
NDTS & -.037 & -.253 & .121 & 1 & -.059 & .170 \\
Profitability & -.189 & .006 & -.441 & -.059 & 1 & -.164 \\
Income & -.577 & .039 & .350 & .170 & -.164 & 1 \\
Variation & & & & & & \\
\hline
\end{tabular}

From Table-1 it can be seen that: the highest correlation value between two variables is -0.577 which shows that a multicollinearity problem is unlikely among the selected independent variables.

\section{Regression Analysis Results}

Table-2: Regression Coefficients and Significance

\begin{tabular}{lcccc}
\hline & Coefficients & $\begin{array}{c}\text { Standard } \\
\text { Error }\end{array}$ & t & Sig. \\
\hline Constant & -.111 & .161 & -.688 & .492 \\
Profitability & -1.147 & .237 & -4.834 & .000 \\
Size & 0.06313 & .023 & 2.754 & .006 \\
NDTS & 3.532 & 1.337 & 2.642 & .009 \\
Tangibility & 0.06108 & .081 & .756 & .450 \\
Income Variation & 18.250 & .635 & 28.754 & .000 \\
Growth & 0.04545 & .003 & 14.818 & .000 \\
& & & & \\
$\mathrm{R}^{2}=0.908$ & & & & \\
Adjusted $\mathrm{R}^{2}=0.906$ & & & & \\
F-Statistic=457 & & & & \\
\hline
\end{tabular}

Table- 2 shows the results of the regression analysis. The value of $\mathrm{R}-$ squared $\left(R^{2}=0.908\right)$ shows that the six variables i.e. growth, size, income variation, profitability, non-debt tax shield (NDTS) and tangibility explain about $90 \%$ of variation in the dependent variable, leverage. This means that 
the choice of capital structure is mainly defined by these six variables in the chemical sector. From the value of the F-statistic it can be seen that the mode1 is significant.

Table-3: Expected and Observed Relationships

\begin{tabular}{llcl}
\hline Determinant & \multicolumn{1}{c}{ Measure } & $\begin{array}{c}\text { Expected } \\
\text { Relationship } \\
\text { with Leverage }\end{array}$ & $\begin{array}{c}\text { Observed } \\
\text { Relation }\end{array}$ \\
\hline $\begin{array}{l}\text { Profitability } \\
\text { Size }\end{array}$ & $\begin{array}{l}\text { EBT/Total Assets } \\
\text { Log of Sales }\end{array}$ & $\begin{array}{c}\text { Negative } \\
\text { Positive }\end{array}$ & $\begin{array}{l}\text { Negative } \\
\text { Positive }\end{array}$ \\
NDTS & $\begin{array}{l}\text { Annual Depreciation/Total } \\
\text { Assets }\end{array}$ & Negative & Positive \\
Tangibility & $\begin{array}{l}\text { Total Gross Fixed } \\
\text { Assets/Total Assets } \\
\text { Income }\end{array}$ & Positive & Positive \\
Variation & $\begin{array}{l}\text { of Years } \\
\text { Annual \%age Change in }\end{array}$ & Negative & Positive \\
Growth & Total Assets & Positive & Positive \\
\hline
\end{tabular}

All results are statistically significant other than tangibility.

Profitability is negatively correlated with leverage. This suggests that profitable firms in the Pakistani chemical sector use more equity and less debt. Thus the conclusion might be that higher profitability keeps firms away from debt instead of encouraging it, exactly as foreseen by the POT. Therefore first hypothesis is accepted. The same results were observed by Shah and Hijazi (2004) and Tariq and Hijazi (2006).

Results show that asset tangibility is positively correlated with leverage. However, evidence was not found that this relationship is statistically significant. Though the positive sign confirms earlier hypotheses about tangibility of assets, the lack of statistical insignificance does not confirm the hypothesis. Thus second hypothesis cannot be accepted. The results thus do not conform to Jensen and Meckling's (1976) and Myers' (1977) version of trade-off theory that debt level should increase with more fixed assets. Shah and Hijazi (2004) observed the same results.

Size is positively correlated with leverage. This suggests that large firms in Pakistan borrow more and small firms are fearful of more debt. This confirms the earlier hypothesis about the size of the firm: that large firms will have a higher level of leverage. This also lends support to the bankruptcy cost theory on leverage; that the fixed direct costs of bankruptcy constitute a smaller portion of the total value of the firm, and thus larger 
firms do not hesitate to take more debt because of fear of bankruptcy. At the same time, the results contradict the Rajan and Zingales (1995) view of less asymmetric information about large firms, suggesting that new equity issue will not be under-priced and thus large firms will issue more equity.

Growth was found to be positively correlated with leverage. This suggests that growing firms in the Pakistani chemical industry use more debt than equity to finance the new projects. One possible reason for this is that in order to grow in the chemical sector, huge cash flows are needed, which a growing firm may not be able to meet through internal sources and therefore they have to rely on debt. This confirms earlier hypotheses about growth opportunities. Tariq and Hijazi (2006) observed a positive relationship between growth and leverage. On the other hand, Shah and Hijazi (2004) found a negative relationship.

The results do not support the simple version of the Pecking Order Theory that suggests growing firms will resort first to internally generated funds to fulfill their financing needs. But it supports the extended version of the Pecking Order Theory that internally generated funds may not be sufficient for growing firms and the next option for such a firm would be to use debt financing.

Income variation was found to be positively correlated with leverage. In Table 1 (independent variable correlations), size is positively correlated with income variation which suggests that large firms in the chemical sector have more income variability than small firms. Bankruptcy cost theory suggests that the fixed direct costs of bankruptcy constitute a smaller portion of the total value of the firm thus larger firms do not hesitate to take more debt. Other reasons can be that the bankruptcy process is slow and inefficient in Pakistan and firms face no or low bankruptcy costs. Furthermore, according to Shah and Hijazi (2004) Pakistani firms have mostly short-term financing as the average firm size is small, which makes access to the capital market difficult in terms of cost and technical difficulties. The main source of debt in Pakistan has been commercial banks, which do not encourage long-term loans (Shah and Hijazi, 2005). So another reason for the positive relationship between income variation and leverage can be that when a firm in the chemical sector faces some loss, then in order to fulfill its requirements it opts for debt financing which is mostly short-term. However, when firms have adequate profits, then it does not finance its operations by debt, as it was observed earlier that leverage is negatively related to profit. The positive relation contradicts earlier hypotheses that income variation is negatively related to leverage. However Cools (1993) says that agency theory suggests a positive relationship between 
earnings volatility and leverage. He says that the problem of underinvestment decreases when the volatility of a firm's returns increases.

Non-debt tax shield (NDTS) is found to be positively related to leverage. The positive relationship between leverage and NDTS is not supported by theory. Literature on capital structure suggests that non-debt tax shields like depreciation reduce the need for debt to stop net income from going to a higher tax bracket, and thus debt should be negatively related to leverage. The most appropriate explanation for the positive relationship of depreciation to debt level can be given from the relevance of NTDS to the capital structure in the Pakistani environment. The corporate tax rate in Pakistan does not vary with the level of income. There are three straight rates; one applicable to public limited companies the second to commercial organizations in government ownership and a third to organizations in the financial sector. Companies in a given group thus face a constant rate of taxation. Depreciation thus does not work as a substitute to debt to stop net income from going into a higher tax bracket. Hence, the positive relationship is only a matter of chance. The positive relationship of NTDS with leverage is not in conformity with earlier hypotheses about NTDS but it supports Bradley et al (1984) that NDTS is positively related to leverage.

\section{Policy Implication and Importance of the Model}

\subsection{Importance for Researchers}

When we look at the data, some firms have more assets than others do and some firms are more profitable than others, so further research can be done by dividing the firms into local and multinational firms and the results could be compared with the combined study of the chemical sector.

Results of the study show that a specific industry exhibits unique attributes which is usually not apparent in the combined analysis of many sectors, and so similar studies can be conducted for other sectors of Pakistan.

\subsection{Importance for Investors and Analyst}

According to the results the model is:

$\mathrm{LG}=-0.111-1.147(\mathrm{PF})+0.06313(\mathrm{SZ})+3.532(\mathrm{NDTS})+0.06108(\mathrm{TG})$

$+18.25(\mathrm{IV})+0.04545(\mathrm{GT})$ 
As this model explains $90 \%$ variation in leverage, it can be used in the analysis of company performance.

By putting values in the equation one can make a judgment about the firm as to how it is financing its assets and comparing it to the overall industry.

For example in 2003 we will find the predicted level of leverage for Colgate Palmolive and than compare it with its actual capital structure.

The sales, EBT, total assets, fixed assets, depreciation and liabilities of Colgate Palmolive for 2003 are:

\begin{tabular}{ccccccc}
\hline Sales & EBT & $\begin{array}{c}\text { Total } \\
\text { Assets } \\
(\mathbf{2 0 0 3 )}\end{array}$ & $\begin{array}{c}\text { Total } \\
\text { Assets } \\
(\mathbf{2 0 0 2})\end{array}$ & Depreciation & Liabilities & $\begin{array}{c}\text { Fixed } \\
\text { Assets }\end{array}$ \\
\hline $3,461.6$ & 270.3 & $1,020.1$ & 849.6 & 28.5 & 551.1 & 336.7 \\
\hline
\end{tabular}

From the above data, values of profitability, size, NDTS, tangibility, income variation and growth are determined which are:

\begin{tabular}{cccccc}
\hline Profitability & Size & NDTS & Tangibility & $\begin{array}{c}\text { Income } \\
\text { Variation }\end{array}$ & Growth \\
\hline 0.265 & 8.15 & 0.028 & 0.33 & 0.00868 & 0.2007 \\
\hline
\end{tabular}

Now putting these values in the model

LG $=-0.111-1.147(0.265)+0.06313(8.15)+3.532(0.028)+$ $0.06108(0.33)+18.25(0.00868)+0.04545(0.2007)$

$\mathrm{LG}=.3860=38.60 \%$

If firms in Chemical Sector of Pakistan have:

\begin{tabular}{cccccc}
\hline Profitability & Size & NDTS & Tangibility & Income Variation & Growth \\
\hline 0.265 & 8.15 & 0.028 & 0.33 & 0.00868 & 0.2007 \\
\hline
\end{tabular}

Then according to the model the level of leverage for that firm will be $38.60 \%$ with $10 \%$ variation.

The actual leverage used by Colgate Palmolive in 2003 was $54.02 \%$ as the difference between $38.60 \%$ and $54.02 \%$ is more than $10 \%$; it means 
that the company is not acting in the same way as the chemical sector as a whole and it has taken additional risk by keeping its level of leverage high.

So along with other ratios, investors can use this model to choose among firms to invest their limited resources and analyst can judge a firm's performance.

\section{Conclusion}

This study has analyzed the determinants of the capital structure by taking the chemical sector of Pakistan as a case study. The study has used a pooled regression model to measure the determinants of capital structure of the firms in the chemical industry.

The motivation for undertaking this study was to address the inadequacies of earlier studies. These studies were based on fewer years of data and less observations. Furthermore, these studies have analyzed the problem using the pooled data for all industries. Based on the empirical results, we conclude that the determinants of capital structure are industry specific. The study also emphasize that more industry specific studies should be undertaken to further explore the problem.

This study has concluded that the relationship between profitability and leverage in the chemical industry of Pakistan follows the pecking order hypotheses.

Besides this, growth which was measured as the annual percentage change in total assets, is positively correlated with leverage. Therefore, we conclude that internally generated funds may not be sufficient for growing firms and debt financing may be the only option for further growth. In addition, the study verifies the positive relationship between variation in income and leverage and non-debt tax shields and leverage. 


\section{References}

Banerjee, S. A. Heshmati, and C. Wihlborg (2000), "The Dynamics of Capital Structure," SSE/EFI Working Paper Series in Economics and Finance 333: 1-20.

Barclay, M. J., C. W. Smith, and R. L. Watts (1995), "The Determinants of Corporate Leverage and Dividends Policies," Journal of Applied Corporate Finance, 7(4): 4-19.

Booth, L V. Aivazian, A. Demirguc-Kunt and V. Maksmivoc (2001), "Capital Structures in Developing Countries,” Journal of Finance 56: 87-130.

Bradley, M., Gregg A. Jarre11, and E. Han Kim (1984), "On the Existence of an Optimal Capital Structure: Theory and Evidence," Journal of Finance 39: 857-878.

Chaplinsky, S. and G. Niehaus (1990), "The Determinants of Inside Ownership and Leverage," University of Michigan, Working Paper, referenced in Harris and Raviv (1991).

Cools, Kees (1993), "Capital Structure Choice; Confronting: (Meta) Theory, Empirical Tests and Execution Opinion," Ph.D Dissertation, Trlburg, the Netherlands.

De Angelo, H and Masulis R.W. (1980), "Leverage and Dividend Irrelevancy Under Corporate and Personal Taxation," Journal of Finance 35(2): 453-64.

Delcoure, N. (2007), "The Determinants of Capital Structure in Transitional Economies," International Review of Economics and Finance, 16(2): 400-415.

Fama, E. (1980), "Agency Problems and Theory of the Firm," Journal of Political Economy, 88(2): 288-307.

Fama, E.F., and K.R. French (2000), "Testing Tradoff and Pecking Order Predictions about Dividends and Debt," University of Chicago, Working Paper 506.

Frank, M.Z, and Goyal, V.K. (2003), "Testing the Pecking Order Theory of Capital Structure," Journal of Financial Economics, 67(2): 217-248. 
Guanqun, Tong, and Christopher, J. Green (2005), "Pecking Order or Trade-Off Hypotheses? Evidence from the Capital Structure of Chinese Campanies," Applied Economics, 37: 2179-2189.

Hall, C. Graham, Hutchinson, J. Patrick and Michaelas (2004), "Determinants of Capital Structure of European SMEs," Journal of Business, Finance, and Accounting, 31.

Harris, M and A Raviv (1990), "Capital Structure and the Informational Role of Debt,” Journal of Finance, 45: 321-349.

Jensen, Michael C. and William H. Meckling (1976), "Theory of the Firm: Managerial Behavior, Agency Costs and Ownership Structure," Journal of Financial Economics, 3: 305-360.

Kester, C. W. (1986), "Capital and Ownership Structure: A Comparison of United States and Japanese Manufacturing Corporations," Financial Management, 15: 5-16.

Lev, B. (1969), "Industry Averages as Targets for Financial Ratios," Journal of Accounting Research, 7: 290-99.

Modigliani, F, and Miller, M.H. (1958), "The Cost of Capital, Corporation Finance and the Theory of Investment," The American Economic Review, 48(3): 261-297.

Modigliani, F. and Miller, M.H. (1963), "Corporate Income Taxes and the Cost of Capital; A Correction," The American Economic Review, 53(3): 433-443.

Myers, S., and N. Majluf (1984), "Corporate Financing and Investment Decisions When Firms Have Information Investors Do Not Have," Journal of Financial Economics, 13: 187-222.

Myers, S.C. (1977), "Determinants of Corporate Borrowing," Journal of Financial Economics, 5: 147-175.

Rajan, R. and Zingales, L (1995), "What Do We Know about Capital Structure? Some Evidence from International Data," Journal of Finance, 50: 1421-1460.

Ross, S.A. (1977), "The Determination of Financial Structure: The Incentive Signaling Approach," Bell Journal of Economics, 8(1): 23-40. 
Scott, J.H. (1977), "Bankruptcy, Secured Debt and Optimal Capital Structure," Journal of Finance, 32: 35-53.

Sevan, A. and Danbolt, J. (2000), "Capital Structure and its Determinants in the United Kingdom: A Decomposition Analysis," SSRN Working Paper Series, Department of Accounting and Finance, University of Glasgow.

Shah, Atta, and Hijazi S. (2004), "The Determinants of Capital Structure in Pakistani Listed Non-Financial Firms," The Pakistan Development Review, 43.

State Bank of Pakistan (1993), "Balance Sheet Analysis of Joint Stock Companies Listed on The Karachi Stock Exchange," Karachi, Pakistan.

State Bank of Pakistan (2004), "Balance Sheet Analysis of Joint Stock Companies Listed on The Karachi Stock Exchange," Karachi, Pakistan.

Stultz, R. (1990), "Managerial Discretion and Optimal Financing Policies," Journal of Financial Economics, 26: 3-27.

Tariq, B. Yasir, and Hijazi S. (2006), "Determinants of Capital Structure: A Case for Pakistani Cement Industry," The Lahore Journal of Economics, 11(1): 63-80.

Titman, S, and Tsyplakov, S. (2005), "A Dynamic Model Capital Structure," SSRN Working Paper Series.

Titman, S. and Wessels, R. (1988), "The Determinants of Capital Structure Choice," Journal of Finance, 43: 1-19.

Wald, J.K. (1999), "How Firms Characteristics Affect Capital Structure: An International Comparison,” Journal of Financial Research, 22: 161187. 